УДК 351:36

B. В. Олійник,

д. держ. упр., заступник директора ННІ неперервної освіти і туризму, професор кафедри публічного управління та менеджменту інновачійної діяльності, Начіональний університет біоресурсів та природокористування України

ORCID ID: 0000-0002-4647-2658

О. П. Алченко,

д. держ. упр., дочент кафедри обліку $і$ оподаткування,

Одесъкий державний аграрний університет

ORCID ID: 0000-0001-9670-2266

DOI: $10.32702 / 2306-6814.2021 .3 .47$

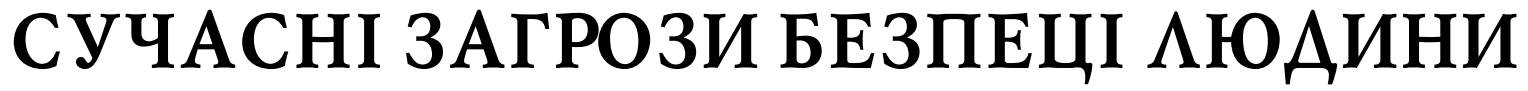 ТА ÏХ ІНАИКАТОРИ В ПУБАІЧНОМУ УПРАВ $\Lambda$ IHHI
}

\author{
V. Oliinyk, \\ Doctor of Sciences in Public Administration, Professor of the Department of Public Administration \\ and Innovation Management, National University of Life and Environmental Sciences of Ukraine \\ O. Diachenko, \\ Doctor of Sciences in Public Administration, Associate Professor, Associate Professor \\ of the Department of Accounting and Taxation, Odessa State Agrarian University
}

\section{MODERN THREATS TO HUMAN SECURITY AND THEIR INDICATORS}

Статтю присвячено дослідженню сучасних загроз безпеці людини та їх індикаторів. Сучасні тенденції розвитку посилюють ризики великомасштабних природних і техногенних катастроф. Інша характерна особливість сучасного розвитку - збільшення небезпек, що загрожують людині постійно. Ризики стають все більш актуальними для кожної людини. Дія загроз безпеці людини обмежує свободу вибору, а також може призвести до крайніх наслідків - кризи або катастрофи. Отримання попередження про такий ризик дозволяє вжити попереджувальних заходів з метою запобігання кризи або пом'якшення її наслідків. Для отримання своєчасної інформації про загрози створюється система раннього попередження - моніторинг безпеки людини. Водночас можливі два підходи - стратегічне попередження і тактичне. Стратегічне попередження - це виявлення загроз, що формуються, і потенційної можливості їх реалізації у майбутньому. Тактичне попередження - виявлення загроз, що вже реалізуються. Існують різні підходи до класифікації загроз і формування системи показників моніторингу. Під час оцінювання загроз економічній безпеці першорядне значення мають показники безробіття - один з головних індикаторів економічної безпеки людини. Зниження надійності доходів - показник нестабільності зайнятості, а також інфляційного знецінення номінальних заробітків. Загрози безпеці здоров'я включають несприятливі умови життя: неповноцінне харчування, небезпечні для здоров'я умови праці, малі та нестабільні доходи, бідність і злидні, зниження доступу до ефективного медичного обслуговування. Забруднення середовища проживання (грунту, питної води, атмосферного повітря, хімічне і радіаційне забруднення харчової продукції) - один 3 основних ризиків для здоров'я. Зростання злочинності-один з головних факторів і характерних ознак збільшення загрози особистій безпеці. Військові та бойові дії (війни між державами, етнічні, релігійні, політичні конфлікти із застосуванням військової сили) також становлять безпосередню небезпеку для життя людини. 
The article is devoted to the study of modern threats to human security and their indicators. Current development trends increase the risks of large-scale natural and man-made disasters. Another characteristic feature of modern development is the increase in the dangers that constantly threaten people. Risks are becoming more and more relevant for each person. Threats to human security limit the freedom of choice, and can also lead to extreme consequences - a crisis or disaster. Receiving a warning about this risk allows you to take preventive measures to prevent a crisis or mitigate its consequences. To get timely information about threats, an early warning system is being created - human security monitoring.

There are two possible approaches: strategic warning and tactical warning. Strategic warning is the identification of emerging threats and the potential for their implementation in the future. Tactical warning-detection of threats that are already being implemented. There are different approaches to classifying threats and creating a system of monitoring indicators. When assessing threats to economic security, unemployment indicators are of primary importance-one of the main indicators of human economic security. Reduced income reliability is an indicator of employment instability, as well as inflationary depreciation of nominal earnings. Threats to health security include poor living conditions: poor nutrition, hazardous working conditions, low and unstable incomes, poverty and destitution, and reduced access to effective health care. Environmental pollution (soil, drinking water, atmospheric air, chemical and radiation contamination of food products) is one of the main health risks. The increase in crime is one of the main factors and characteristic signs of an increased threat to personal security. Military and military actions (wars between States, ethnic, religious, political conflicts involving the use of military force) also pose an immediate danger to human life.

Ключові слова: безпечне середовище, безпека, безпекажиттєдіяльності, моніторинг, економічна безпека, публічне управління.

Key words: safe environment, safety, life safety, monitoring, economic security, public administration.

\section{ПОСТАНОВКА ПРОБАЕМИ}

Сучасні тенденції розвитку посилюють ризики великомасштабних природних і техногенних катастрофр. Інша характерна особливість сучасного розвитку збільшення небезпек, що загрожують людині постійно. Різке прискорення ритму життя і підвищення нестабільності розвитку сприяють зростанню вразливості людини в повсякденному житті. Ризики втрати робочого місця, доходів, забруднення середовища проживання, хвороб, загрози насильства стають все більш актуальними для кожної людини.

\section{АНААIЗ ОСТ АНHIX АОС $А$ КЖЕНЬ ТА ПУБАІКАЦІЙ}

Нині існує велика кількість наукових праць, які висвітлюють питання забезпечення безпечного середовища для життя громадян. Вивченню проблем безпеки присвячені сучасні дослідження науковців І. Гришової [5; 6], І. Грищенко [1; 2], О.Дяченка [4], О. Ковальової [8; 9], О. Ніколюк [11], І. Мищака, О. Резнікова, Б. Парахонського, В. Хаустовой, Т. Шабатури, Г. Яворської та ін., які свідчать про те, що безпека розглядається як захищеність від природних і суспільних катаклізмів і сприймається як одна з основоположних цінностей буття людини. Проте досі $є$ недостатньо дослідженими питання концептуальних підходів до визначення поняття "безпечне середовище життя" та його складових.

\section{META CTATTI}

Метою статті $є$ дослідження сучасних загроз безпеці людини та їх індикаторів.

\section{ВИК ААА ОСНОВНОГО МАТЕРІААУ}

Різнопланові загрози наразі стали постійним елементом щоденного життя людей. Враховуючи це, в "українському суспільстві сорормовано стереотип людиноцентричного підходу як моделі державного управління, суттю якої є постановка в центр діяльності держави задоволення потреб людини. Це чітко простежується в Програмі Кабінету Міністрів України на 2020 рік, у якій визначено, що "держава це створений громадянами сервіс, головним завданням якого $€$ вирішення існуючих проблем та відвернення потенційних загроз для громадян шляхом забезпечення балансу інтересів різних частин суспільства".

Досліджуючи цю програму науковець І. Грищенко звертає увагу, що в ній згадується про небезпеки з боку "сильних монополій і неформальних груп впливу; військовий конфлікт на частині території Донецької та Луганської областей; втрату контролю над територією Автономної Республіки Крим; загрозу продовження агресивних дій Російської Федерації" [1, с. 33].

Інша загроза, яка детально описана в статті "Причини та наслідки пандемії COVID-19: уроки для України та світу" - це пандемія коронавірусу, яка "змусила світову спільноту по-новому поглянути на виклики, що загрожують людству, показала взаємозалежність глобальних загроз одна від одної і кумулятивний негативний ефект, спричинений невчасним реагуванням всіх суб'єктів прийняття управлінських рішень на всіх рівнях управління. Пандемія COVID-19 змусила світову спільноту переосмислити підходи до зовнішніх загроз і змін, які вони несуть, адже спочатку ніхто не вірив у реальну 
загрозу коронавірусної інфрекції, а в подальшому всі впевнилися у незворотностіїї руйнівної сили" [2].

Загалом дія загроз безпеці людини обмежує свободу вибору, а також може призвести до крайніх наслідків - кризи або катастрофи. Отримання попередження про такий ризик дозволяє вжити попереджувальних заходів з метою запобігання кризи або пом'якшення ії̈ наслідків. Для отримання своєчасної інфрормації про загрози створюється система раннього попередження - моніторинг безпеки людини. При цьому можливі два підходи - стратегічне попередження і тактичне. Стратегічне попередження - це виявлення загроз, що формуються, і потенційної можливості їх реалізації в майбутньому. Тактичне попередження - виявлення загроз, що вже реалізуються. Система стратегічного попередження визначає можливість впливу на загрози безпеці людини до того моменту, коли вони можуть остаточно сорормуватися і бути реалізовані. Відповідно вона дозволяє розширити спектр варіантів політики і вибір ії засобів [3].

Існують різні підходи до класифікації загроз і формування системи показників моніторингу. Слід погодитися з думкою, що необмежене розширення системи індикаторів розчиняє проблему безпеки в загальних характеристиках соціально-економічного розвитку, і тому вибірковий підхід кращий.

Попри різноманіття підходів до вибору конкретних індикаторів, можна виділити групу показників, які складають основу системи попередження.

Відповідний набір індикаторів і заснована на ньому система раннього попередження складається в кожному конкретному випадку виходячи з поставлених цілей і можливості отримання необхідної статистичної інфрормації. Соціальна статистика не має в своєму розпорядженні багатьох показників, що застосовуються на міжнародному рівні. Особливо це стосується показників продовольчої, екологічної та політичної безпеки. Через недосконалість і обмеженість статистичної інфрормації ще більш ускладнюється завдання моніторингу безпеки людини на регіональному рівні.

Накопичений теоретичний і практичний досвід попередження кризових явищ дозволив виробити певні порогові значення індикаторів, що представляють собою кількісне вираження меж розвитку, порушення яких свідчить про наявність загроз безпеки людини і ризик виникнення криз [4].

Оскільки вимірювання багатьох аспектів безпеки людини носить умовний, непрямий характер, то не завжди можна встановити кількісно виражений гранично критичний рівень, хоча такі спроби робляться. Крім того, необхідно враховувати, що вживання поняття "гранична величина" і визначення її математичними методами іноді може бути соціально неприйнятним і некоректним з точки зору розвитку людини і суспільства. Тому відносно деяких показників більш поширене застосування методу порівняння з досягнутим рівнем (в минулому періоді, інших регіонах з більш сприятливими параметрами людського розвитку і т.д.) за умови дотримання принципів зіставлення.

При оцінці загроз економічній безпеці першорядне значення мають показники безробіття - один з головних індикаторів економічної безпеки людини. Мож- ливість заняття оплачуваною працею - умова запобігання загрози злиднів і її наслідків для людини. Збільшення в структурі зайнятості" ризикованої зайнятості", переважно контрактної форми найму працівників означає тимчасову або часткову зайнятість і надає менші гарантії збереження робочого місця і доходів, а також призводить до підвищення рівня тіньової економіки, яка в цілому негативно впливає на економічний розвиток держави та людини зокрема [5, с. 186].

Зниження надійності доходів - показник нестабільності зайнятості, а також інфляційного знецінення номінальних заробітків.

Загрози продовольчій безпеці оцінюється на основі аналізу наступних показників: добове споживання калорій у відсотках до мінімальної потреби; індекс виробництва продуктів харчування на душу населення; коефіцієнт залежності від імпорту продукції [6, с. 120].

Загрози екологічної безпеки визначається радіаційним забрудненням, хімічним забрудненням навколишнього середовища, геомагнітними та електромагнітними випромінюваннями.

Крім того, розвиток і впровадження нових біотехнологій пов'язане не тільки з вигодою, але і з ризиком для навколишнього середовища і здоров'я людини. В інтересах отримання комерційної вигоди транснаціональні компанії, що контролюють ринок нових біотехнологій, сприяють їх прискореному впровадженню без достатнього врахування наслідків. Розробка проблем біобезпеки та вжиття відповідних заходів захисту в інтересах людей значно відстають від темпів і масштабів впровадження нових біотехнологій.

Загрози безпеці здоров'я включають несприятливі умови життя: неповноцінне харчування, небезпечні для здоров'я умови праці, малі та нестабільні доходи, бідність і злидні, зниження доступу до ефективного медичного обслуговування.

Забруднення середовища проживання (грунту, питної води, атмосферного повітря, хімічне і радіаційне забруднення харчової продукції) - один з основних ризиків для здоров'я. Екологічні ризики стають всеохоплюючими та визначальними. Наприклад, у структурі таких ризиків, як погане харчування або житло, починає переважати екологічна компонента неблагополуччя [7].

Нерегульовані екологічні параметри житлово-побутових умов населення створюють додатковий і істотний ризик для здоров'я. Це стосується передусім якості будівельних матеріалів і місця розташування житла. Не враховуються такі фрактори, як геліомагнітні лінії, електромагнітне і радіоактивне випромінювання, загазованість, шум і т.д. нерідко в безпосередній близькості або навіть в самих житлових приміщеннях розміщуються лабораторії і різні установки, які надають шкідливий вплив на здоров'я людини. Екологічні характеристики житла в сучасному вітчизняному містобудуванні не враховуються.

Ризики нових біотехнологій можуть бути особливо небезпечними для здоров'я людини і довготривалих перспектив розвитку суспільства. Проблема посилюється в країнах з нерозвиненою демократією, недостатнім освітнім рівнем і монополізацією засобів масової інформації. Крім того, прискорення ритму життя призводить 
до впровадження технологій з непередбачуваними наслідками [8].

Особливий ризик представляє материнська смертність як один із наслідків збільшення сукупності ризиків: несприятливі умови життя, відсутність ефективної медичної допомоги, екологічне неблагополуччя.

Загрози особистої безпеки включають природні і техногенні аварії і катастрофи; ризик нещасних випадків на виробництві, на транспорті, в побуті; смертність від дорожніх пригод і т. д.

Зростання злочинності - один з головних фракторів і характерних ознак збільшення загрози особистій безпеці. Наявність численних передумов зростання злочинності (в тому числі економічних умов) створює вкрай несприятливу криміногенну обстановку. Висока частка особливо небезпечної насильно-корисливої злочинності. Збільшуються масштаби діяльності організованих злочинних груп. Різко зростає кількість злочинів у стані сп'яніння і пов'язаних з прийомом наркотиків. Збільшується число злочинів, скоєних із застосуванням вогнепальної зброї та вибухових пристроїв, вбивства за наймом, рекет, захоплення заручників, шантаж, тероризм. Безпосередню небезпеку становить також інтенсивне зростання економічних злочинів - помилкова реклама, продаж недоброякісної продукції, фальшивомонетництво тощо.

Військові та бойові дії (війни між державами, етнічні, релігійні, політичні конфлікти із застосуванням військової сили) також становлять безпосередню небезпеку для життя людини.

Насильство держави (фрізичні тортури, примусові роботи в зонах підвищеної небезпеки для здоров'я і життя і т.д.), насильство над дітьми і жінками, насильство на роботі, зростання психічного насильства - характерні риси сучасного розвитку, що представляють загрозу здоров'ю і життю людини.

Загрози політичній безпеці характеризуються політичними переслідуваннями, систематичними тортурами, жорстоким поводженням; репресіями з боку держави по відношенню до окремих осіб і груп; контролем сорери ідеології та інформації [9].

Загрози культурної та громадської безпеки викликають руйнування традиційних спільнот - сім'ї, громади, організації, етнічної групи, деструктивні тенденції в розвитку суспільства, які не піддаються точному кількісному вимірюванню, але за силою руйнівного впливу можуть мати катастрофрічні наслідки.

Культурне різноманіття визнається цінністю і неринковим ресурсом розвитку суспільства. Його зменшення має безліч негативних наслідків для прогресу розвитку людини і суспільства.

Монополізація засобів масової інфрормації створює у суспільстві стереотипи поведінки і ціннісні установки, що відповідають інтересам компаній, контролюючих ці кошти, і може становити небезпеку для розвитку суспільства. У формуванні суспільної свідомості значне місце займають засоби масової інфрормації. Переваги розвитку сучасних інформаційних і комунікаційних технологій використовуються не тільки в благих цілях: створюються сприятливі умови для маніпулювання суспільною свідомістю. Монополія на засоби масової інформації сприяє впровадженню в масову свідомість ідей, цінностей, установок, що відповідають інтересам контролюючих осіб.

Аналізуючи інформаційну функцію органів конституційної юрисдикції, потрібно підкреслити, що вона відіграє суттєве значення для функціонування як органів державної влади так і для життя звичайних громадян. Очевидно, що в сучасному світі безпрецедентно зросла роль інформації в суспільстві. А тісна взаємодія інформаційної діяльності органів конституційної юрисдикції з реалізацією таких принципів, як гласність та відкритість лише підсилює роль інформаційної функції. Адже від доступності, кількості інформації і методів іії доведення залежить ефективність фрормування громадської думки, і в цьому виявляється зв'язок між інформацією та демократичним суспільством [10].

Поглиблення нерівності можливостей між соціальними, етнічними, релігійними групами, сільським і міським населенням, між населенням різних територій при досягненні певної (критичної) позначки призводить до соціальної напруженості і конфліктів і може перерости в кризу. Наприклад, етнічні та релігійні конорлікти переростають у військові.

Культурне, етнічне, релігійне різноманіття, яке створює міграція, - не тільки цінність суспільного розвитку, а й джерело соціальної напруженості і конфліктів. Економічна, політична і соціальна нерівність між мігрантами і основним населенням при підвищеній міграції сприяє виникненню конфліктів. Надмірний міграційний тиск також викликає руйнування окремих етносів.

Зниження народжуваності, високе зростання смертності, у тому числі осіб працездатного віку, скорочення приросту населення, висока дитяча та дитяча захворюваність створюють загрозу депопуляції. Загроза широкого поширення псевдокультурних знань і цінностей сприяє створенню фріктивного людського і соціального капіталу, який не піддається точному кількісному вимірюванню, але може зіграти "доленосну" роль у розвитку (деградації) суспільства. Виражається в низькому профресіоналізмі, зниженні значущості моральних норм, створенні культу помилкових цінностей і т. д. Торгівля наркотиками і поширення наркоманії - одна з найбільш руйнівних загроз людському суспільству.

У рамках Концепції національної або державної безпеки будують зміст концептуальних положень на основі виокремлення та врахування кількох основних видів загроз безпеці, а саме:

1) зовнішні (виходять ззовні, пов'язані зі спробами підпорядкувати державу іншій державі) та внутрішні (пов'язані зі станом самої держави);

2) реальні та потенційні;

3) глобальні, регіональні та локальні.

\section{ВИСНОВКИ І ПЕРСПЕКТИВИ \\ ПОАААЬШИХ АОС АІАЖЕНЬ}

Таким чином, безпека людини - найважливіший аспект якості життя. Попри різноманіття підходів до вибору конкретних індикаторів, можна виділити групу показників, які складають основу системи попередження. Відповідний набір індикаторів і заснована на ньому система раннього попередження складається в кожному конкретному випадку, виходячи з поставлених цілей і можливості отримання необхідної статистичної інфрор- 
мації. Зростання злочинності - один з головних фракторів і характерних ознак збільшення загрози особистій безпеці. Наявність численних передумов зростання злочинності (в тому числі економічних умов) створює вкрай несприятливу криміногенну обстановку.

\section{Література:}

1. Грищенко І. Програма діяльності Кабінету Міністрів України в аспекті консолідації та розвитку української нації. Збірник наукових праць Національної академії державного управління при Президентові України. 2020. Вип. 1. С. 33-40. URL: http://zbirnyk-nadu.academy.gov.ua/article/view/208994/209142 (дата звернення 15.01.2021р.).

2. Грищенко І. Причини та наслідки пандемії COVID19: уроки для України та світу. Збірник наукових праць Національної академії державного управління при Президентові України. 2020. Вип. 2. С. 89-99.

3. Парахонський Б.О., Яворська Г.М. Міжнародне безпекове середовище: виклики і загрози національній безпеці України. К.: НІСД, 2013. 56 с.

4. Gryshova I., Nikoliuk O., Marchuk L. Institutional aspects of the regulation of economic security of the agricultural production / / Food Industry Economics. 2019. Vol.11, Issue 3. P. 23-32. doi: 10.15673/fie.v11i3.1458

5. Гришова І.Ю., Дяченко О.П. Дієвість механізмів державного управління в сфрері протидії тіньовій економіці в Україні. Право та державне управління. 2016. № 3. С. $183-189$.

6. Русан В.М., Дяченко О.П. Інституційні засади розвитку аграрного сектору у контексті забезпечення економічної безпеки держави. Наукові записки Інституту законодавства Верховної Ради України. 2019. № 2. С. $117-122$.

7. Ковальова О.В. Стиренко Л. М. Екологічна безпека органічної продукції: міжнародний досвід. Zbior artykulow naukowych z Konferencji Miedzynarodowej Naukowo Praktycznej (on-line) zorganizowanej dla pracownikow naukowych uczelni, jednostek naukowobadawczych oraz badawczych z panstw obszaru bylego Zwiazku Radzieckiego oraz bylej Jugoslawii (30.06.2020) - Warszawa, 2020. P. 30-33.

8. Ковальова О.В. (2020). Інноваційний інструментарій структурної політики управління розвитком аграрного сектору економіки. Наукові записки Інституту законодавства Верховної Ради України 2020. №2. С. 99108. https://doi.org/10.32886/instzak.2020.02.11

9. Nikoliuk O., Donets L., Klevets M. Reversed forms of globalization and their impact on the system of public administration. Food Industry Economics. 2020. Vol.12, Issue 1. P. 95-100. doi:10.15673/fie.v12i1.1673

10. Дяченко О.П., Ніколюк О.В., Мужайло В.Д. Орган конституційної юрисдикції в механізмі державних органів влади: до питання реалізації окремих функцій. Державне управління: удосконалення та розвиток. 2020. № 5. URL: http://www.dy.nayka.com.ua/ ?op $=1 \& z=1687$ (дата звернення: 02.02.2021). DOI: 10.32702/2307-2156-2020.5.1

References:

1. Hryschenko, I. (2020), "Program of activities of the Cabinet of Ministers of Ukraine in the aspect of consolidation and development of the Ukrainian nation", Zbirnyk naukovykh prats' Natsional'noi akademii derzhavnoho upravlinnia pry Prezydentovi Ukrainy, vol. 1, pp. 33-40, available at: http://zbirnyk-nadu.academy.gov.ua/article/view/208994/209142 (Accessed 15 Jan 2021).

2. Hryschenko, I. (2020), "Causes and consequences of the COVID-19 pandemic: lessons for Ukraine and the world", Zbirnyk naukovykh prats' Natsional'noi akademii derzhavnoho upravlinnia pry Prezydentovi Ukrainy, vol. 2, pp. 89-99.

3. Parakhons'kyj, B.O. and Yavors'ka, H.M. (2013), Mizhnarodne bezpekove seredovysche: vyklyky i zahrozy natsional'nij bezpetsi Ukrainy [International security environment: challenges and threats to Ukraine's national security], NISD, Kyiv, Ukraine.

4. Gryshova, I. Nikoliuk, O. and Marchuk, L. (2019), "Institutional aspects of the regulation of economic security of the agricultural production", Food Industry Economics, Vol.11, no. 3, pp. 23-32. doi: 10.15673/ fie.v11i3.1458

5. Hryshova, I.Yu. and Diachenko, O.P. (2016), "The effectiveness of public administration mechanisms in the field of combating the shadow economy in Ukraine", Pravo ta derzhavne upravlinnia, vol. 3, pp. 183189.

6. Rusan, V.M. and Diachenko, O.P. (2019), "Institutional principles of agricultural sector development in the context of ensuring economic security of the state", Naukovi zapysky Instytutu zakonodavstva Verkhovnoi Rady Ukrainy, vol. 2, pp. 117-122.

7. Koval'ova, O.V. and Styrenko, L.M. (2020), "Ecological safety of organic products: international experience", Zbior artykulow naukowych z Konferencji Miedzynarodowej Naukowo Praktycznej (on-line) zorganizowanej dla pracownikow naukowych uczelni, jednostek naukowo-badawczych oraz badawczych z panstw obszaru bylego Zwiazku Radzieckiego oraz bylej Jugoslawii [Collection of scientific articles from the International Scientific and Practical Conference (on-line) organized for academics of universities, research and development units from the former Soviet Union and former Yugoslavia], Warszawa, Poland, 30.06.2020, pp. $30-33$.

8. Koval'ova, O.V. (2020), "Innovative tools of structural policy of management of development of agrarian sector of economy", Naukovi zapysky Instytutu zakonodavstva Verkhovnoi Rady Ukrainy, vol. 2, pp. 99108. https://doi.org/10.32886/instzak.2020.02.11

9. Nikoliuk, O. Donets, L. and Klevets, M. (2020), "Reversed forms of globalization and their impact on the system of public administration", Food Industry Economics, vol.12, no. 1, pp. 95-100. doi:10.15673/ fie.v12i1.1673

10. Diachenko, O., Nikoliuk, O. and Muzhailo, V. (2020), "Constitutional jurisdiction authority in the mechanism of state authorities: to the issue of realization of individual functions", Derzhavne upravlinnya: udoskonalennya ta rozvytok, [Online], vol. 5, available at: http://www.dy.nayka.com.ua $/$ ?op $=1 \& z=1687$ (Accessed 03 Feb 2021). DOI: 10.32702/2307-2156-2020.5.1

Стаття надійшла до редакиї 03.02.2021 p. 